\title{
Spatial distribution of pollutants in the area of the former CHP plant
}

\author{
Robert Cichowicz, ${ }^{1, *}$ \\ ${ }^{1}$ Lodz University of Technology, Faculty of Architecture, Civil and Environmental Engineering, \\ Al. Politechniki 6, 90-924 Łódź, Poland
}

\begin{abstract}
The quality of atmospheric air and level of its pollution are now one of the most important issues connected with life on Earth. The frequent nuisance and exceedance of pollution standards often described in the media are generated by both low emission sources and mobile sources. Also local organized energy emission sources such as local boiler houses or CHP plants have impact on air pollution. At the same time it is important to remember that the role of local power stations in shaping air pollution immission fields depends on the height of emitters and functioning of waste gas treatment installations. Analysis of air pollution distribution was carried out in 2 series/dates, i.e. 2 and 10 weeks after closure of the CHP plant. In the analysis as a reference point the largest intersection of streets located in the immediate vicinity of the plant was selected, from which virtual circles were drawn every 50 meters, where 31 measuring points were located. As a result, the impact of carbon dioxide, hydrogen sulfide and ammonia levels could be observed and analyzed, depending on the distance from the street intersection.
\end{abstract}

\section{Introduction}

Formation of air, water and soil pollutants has always been inseparably linked with the history of human development. The problem of environmental pollution is to be considered both globally [1-6] and locally [7-12], since individual elements can affect the environment at different scales and at different times. This is a result of the simultaneous increase of industrial production, and consequently the increase of demand for heat and electricity, as well as the systematic increase of population and of its density in a given area and the creation or development of the so-called urban and rural tissue [13-15].

Therefore, in order to ensure that present and future generations can live in a unpolluted environment, pollution from anthropogenic sources, including in particular those related to energy industry and transportation should be controlled and reduced [16-19].

At the same time, the question arises: what to do with objects or entire areas that were previously heavily exploited, e.g. as a result of the operation of CHP plants, and have become degraded. The solution may be to carry out the reclamation and/or revitalization of such sites. This is especially true in cities where old boiler houses, heating plants and CHP

\footnotetext{
${ }^{*}$ Corresponding author: robert.cichowicz@.p.lodz.pl
} 
plants are located in the centers, and now their look and pollution of the neighborhood arouse repulsive sensations [20-21].

For this reason, it seems interesting to analyze such air pollutants as carbon dioxide $\left(\mathrm{CO}_{2}\right)$, hydrogen sulfide $\left(\mathrm{H}_{2} \mathrm{~S}\right)$ and ammonia $\left(\mathrm{NH}_{3}\right)$, especially when it refers to the area of nearly 20 hectares of a former CHP plant located in the vicinity of residential and commercial buildings and in the immediate vicinity of a big city center. In the world such objects/sites have now a second youth because of problems with the so-called urban sprawl which generates more and more costs and introduces additional planning and urban constraints. Therefore, more and more often a so-called 'return to the center' is observed. This, however, must be safe for future users [22-24].

The three selected pollutants are very common during the operation and closing of such industrial plants. Their excessive concentrations are or may be hazardous to human health (Table 1).

Table 1. Maximum allowable concentrations (MAC) of carbon dioxide $\left(\mathrm{CO}_{2}\right)$, hydrogen sulfide $\left(\mathrm{H}_{2} \mathrm{~S}\right)$ and ammonia $\left(\mathrm{NH}_{3}\right)$ in selected countries [25-28].

\begin{tabular}{|c|c|c|c|c|c|c|}
\hline \multirow[b]{2}{*}{ Country } & \multicolumn{2}{|c|}{ Carbon dioxide $\left(\mathrm{CO}_{2}\right)$} & \multicolumn{2}{|c|}{ Hydrogen sulfide $\left(\mathrm{H}_{2} \mathrm{~S}\right)$} & \multicolumn{2}{|c|}{ Ammonia $\left(\mathrm{NH}_{3}\right)$} \\
\hline & $\begin{array}{l}\text { MAC, } \\
\mathrm{mg} / \mathrm{m}^{3} \\
(\mathrm{ppm})\end{array}$ & $\begin{array}{c}\text { Instantaneous } \\
\text { MAC, } \mathbf{m g} / \mathbf{m}^{3} \\
(\mathrm{ppm})\end{array}$ & $\begin{array}{l}\mathrm{MAC}, \\
\mathrm{mg} / \mathrm{m}^{3} \\
(\mathrm{ppm})\end{array}$ & $\begin{array}{c}\text { Instantaneous } \\
\text { MAC, } \mathbf{m g} / \mathbf{m}^{3} \\
(\mathrm{ppm})\end{array}$ & $\begin{array}{l}\text { MAC, } \\
\mathrm{mg} / \mathrm{m}^{3} \\
(\mathrm{ppm})\end{array}$ & $\begin{array}{c}\text { Instantaneous } \\
\text { MAC, } \mathbf{m g} / \mathrm{m}^{3} \\
(\mathrm{ppm})\end{array}$ \\
\hline Belgium & $\begin{array}{c}9131 \\
(5000)\end{array}$ & $54784(30000)$ & $7(5)$ & $14(10)$ & $\begin{array}{c}14 \\
(20)\end{array}$ & $36(50)$ \\
\hline France & $\begin{array}{c}9000 \\
(5000)\end{array}$ & - & $7(5)$ & $14(10)$ & $7(10)$ & $14(20)$ \\
\hline Germany & $\begin{array}{c}9100 \\
(5000)\end{array}$ & $18200(10000)$ & $7.1(5)$ & $14.2(10)$ & $\begin{array}{c}14 \\
(20)\end{array}$ & $28(40)$ \\
\hline Poland & 9000 & 27000 & 7 & 14 & 14 & 28 \\
\hline Sweden & $\begin{array}{c}9000 \\
(5000)\end{array}$ & $18000(10000)$ & $7(5)$ & $14(10)$ & $\begin{array}{c}14 \\
(20)\end{array}$ & $36(50)$ \\
\hline $\begin{array}{l}\text { Great } \\
\text { Britain }\end{array}$ & $\begin{array}{c}9150 \\
(5000)\end{array}$ & $27400(15000)$ & $7(5)$ & $14(10)$ & $\begin{array}{c}18 \\
(25)\end{array}$ & $25(35)$ \\
\hline $\begin{array}{l}\text { USA: } \\
\text { - NIOSH }\end{array}$ & $\begin{array}{c}9000 \\
(5000)\end{array}$ & $54000(30000)$ & - & $15(10)$ & $\begin{array}{c}18 \\
(25)\end{array}$ & $27(35)$ \\
\hline - OSHA & $\begin{array}{c}9000 \\
(5000)\end{array}$ & - & (4) & $\begin{array}{l}30(20) \\
70(50)\end{array}$ & $\begin{array}{c}35 \\
(50)\end{array}$ & - \\
\hline UE & $\begin{array}{c}9000 \\
(5000)\end{array}$ & - & $7(5)$ & $14(10)$ & 14 & 36 \\
\hline
\end{tabular}

\section{Methodology of measurements}

The EC-2 plant (Fig. 1) is located in Lodz (Poland) in the district of Górna at the intersection of Wróblewskiego Street and Aleja Politechniki. The analyzed area in the north-west and west is adjacent to industrial buildings, while in the north, east, south and south-west direction with residential development. Additionally, in the north and east 300 $\mathrm{m}$ from the site there are 3 and 11 storey buildings (these are mainly the buildings belonging to the Lodz University of Technology: 19th century palaces and revitalized post office buildings, as well as student houses inhabited for 10 months a year).

Therefore, it can be assumed that around the former EC-2 plant dominate buildings with a height exceeding $5 \mathrm{~m}$, for which the average coefficient of aerodynamic roughness is $2 \mathrm{~m}$. 
At the same time, according to [29-30], on the area affected by the EC-2 plant operation there have been no national parks or forest complexes and spa areas or historical monuments included in the World Heritage List as well as the areas belonging to the European network Natura 2000.

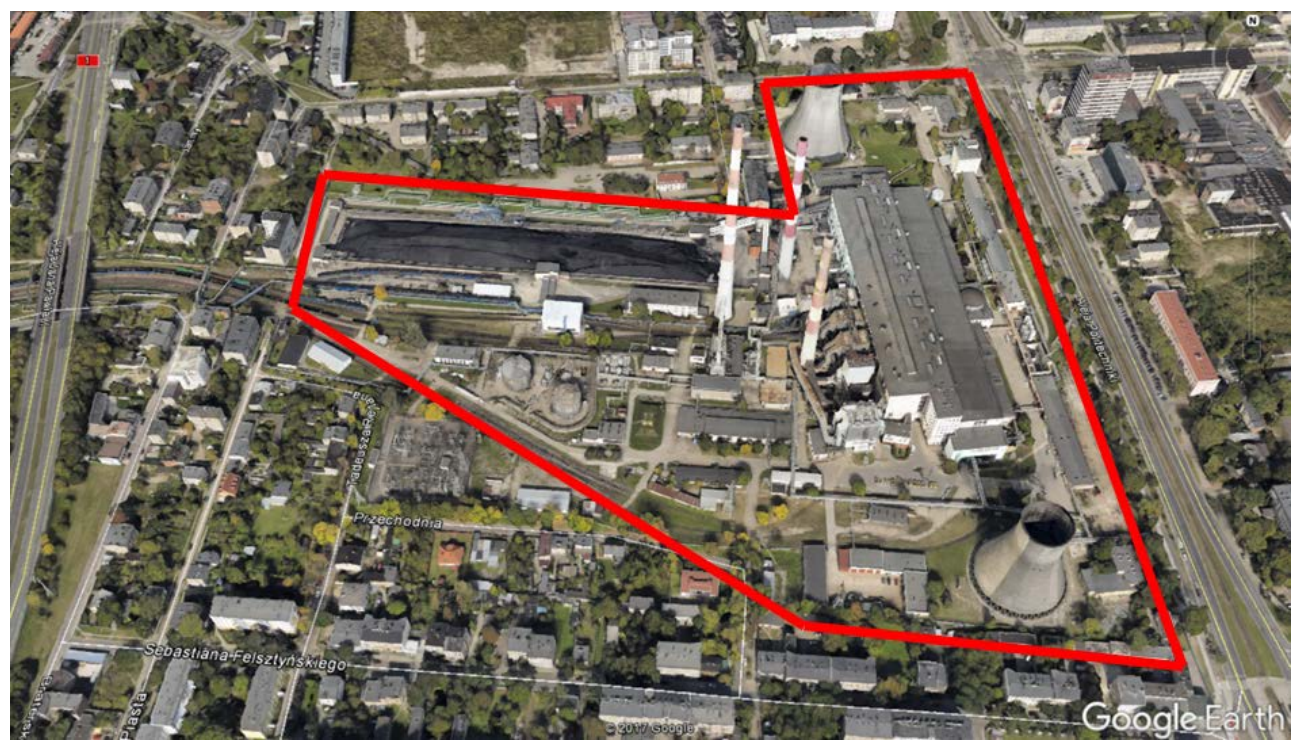

Fig. 1. Location of the analyzed CHP plant, i.e. EC-2 plant in Łódź [31].

The largest intersection of streets in the immediate vicinity of the studied site was chosen in the analysis as a reference point from which every $50 \mathrm{~m}$ virtual circles were drawn (Fig. 2) with 31 measuring points located on them (Fig. 3). For measurements, a VEGA-GC micro-chromatograph [32] was used, which allowed for analysis in field conditions. The device was equipped with 2 batteries, a tank with carrier gas (helium), sample pump and computer module, as well as 2 parallel columns to measure $\mathrm{CO}_{2}, \mathrm{H}_{2} \mathrm{~S}$ and $\mathrm{NH}_{3}$. The micro-chromatograph had a thermal conductivity detector (TCD) capable of analyzing samples with a minimum concentration of $500 \mathrm{ppb}(0.005 \mathrm{ppm})$ in 6 to 300 seconds depending on the type of gas being tested.

A method for measurement of gaseous pollutants developed by Cichowicz [33-34] was used. Location of the measuring points on the virtual circles was dependent on the possibility of safe and repeatable adjustment of the device (at each measuring point three samples of air were taken). The measurements were carried out in 2 series/dates, i.e. 2 and 10 weeks after closing the CHP plant (17 April 2015 and 11 June 2015). During each measurement series, the concentration of pollutants was analyzed in 31 selected measuring points located on the circle lines with a common central point located at the crossing of the Wróblewskiego Street and Aleja Poltechniki, every $50 \mathrm{~m}$ (according to Fig. 2), collecting and analyzing three times the air sample at a 90 second interval and for further analysis taking the average value. At each measuring point, $\mathrm{CO}_{2}, \mathrm{H}_{2} \mathrm{~S}, \mathrm{NH}_{3}$ and air temperature, as well as the wind direction and velocity were measured. The information on pressure and relative humidity was read from the meteorological station located about $5 \mathrm{~km}$ in a straight line from the Reymont airport in Łódź [35]. The measuring device was always positioned in the direction free from buildings and additionally an external device equipped with a GPS receiver was used. In the moment when a sample was dosed, the device recorded date, time and coordinates from the GPS system on the memory card (Table 2). 


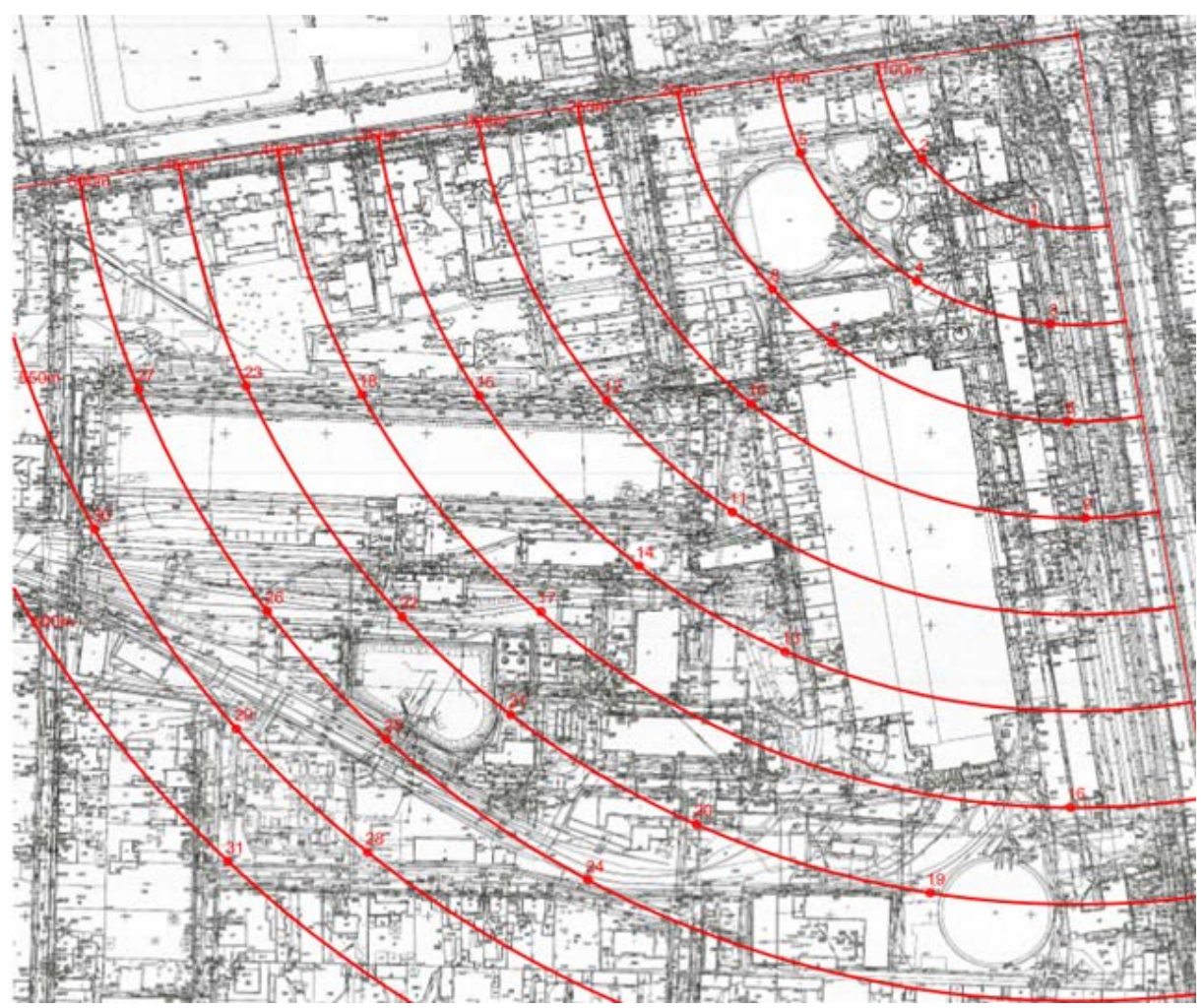

Fig. 2. Location of measuring points at EC-2 plant area.

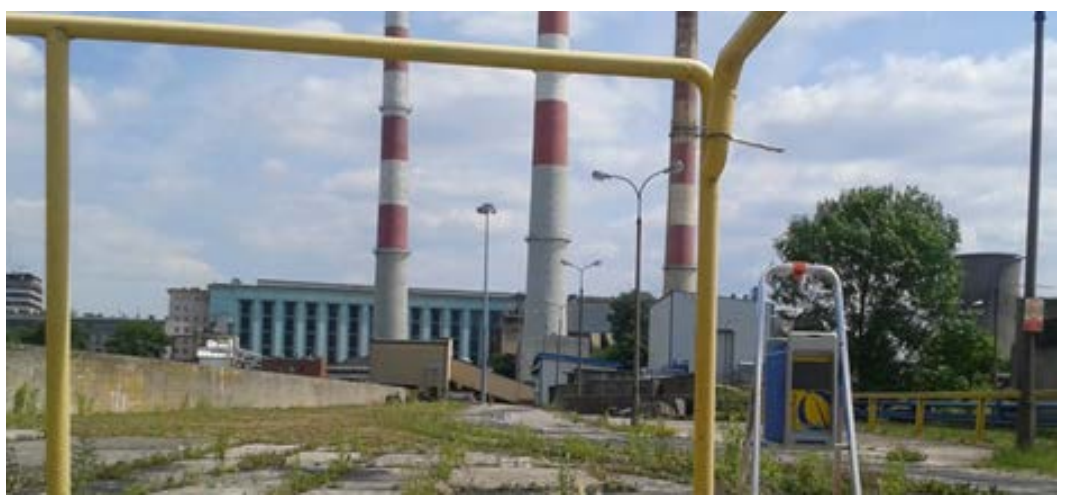

Fig. 3. Location of the measuring point.

Table 2. Parameters necessary for numerical analyses (boundary conditions) [35].

\begin{tabular}{|c|c|c|}
\hline Date of measurement/ Parameter & $\mathbf{1 7 . 0 4 . 2 0 1 5}$ & $\mathbf{1 1 . 0 6 . 2 0 1 5}$ \\
\hline Temperature $\left[{ }^{\circ} \mathrm{C}\right]$ & $-3 \div-1$ & $5 \div 7$ \\
\hline Cloudiness & light overcast & sunny \\
\hline Wind flow velocity $[\mathrm{km} / \mathrm{h}]$ & $13 \div 15$ & $9 \div 13$ \\
\hline Wind direction & $\mathrm{W} \div \mathrm{NW}$ & $\mathrm{SW}$ \\
\hline Pressure $[\mathrm{hPa}]$ & 1011 & 1022 \\
\hline Relative humidity $[\%]$ & $40 \div 58$ & $31 \div 43$ \\
\hline
\end{tabular}




\section{Results of measurement}

The measurements together with the analysis of literature data [29-30] are aimed at verifying if the area of the former CHP plant affects the environment (does not exceed the permissible air quality standards - Table 1) and if it might be subjected to post-industrial space revitalization.

On the virtual circles there were measuring points at which the following atmospheric air pollutants were measured: $\mathrm{CO}_{2}$ (Fig. 4), $\mathrm{H}_{2} \mathrm{~S}$ (Fig. 5) and $\mathrm{NH}_{3}$ (Fig. 6). All results obtained are below the maximum limit concentrations of specific pollutants and therefore do not adversely affect air quality in the analyzed area. It would be advisable to carry out this analysis again after a longer period of time to check the trend line for different levels of pollution and to eliminate the impact of the decommissioning activities that took place on the area of the former CHP plant during the two measurement series. In addition, to complete the knowledge of this area it might be useful to analyze pollutants present in the soil.

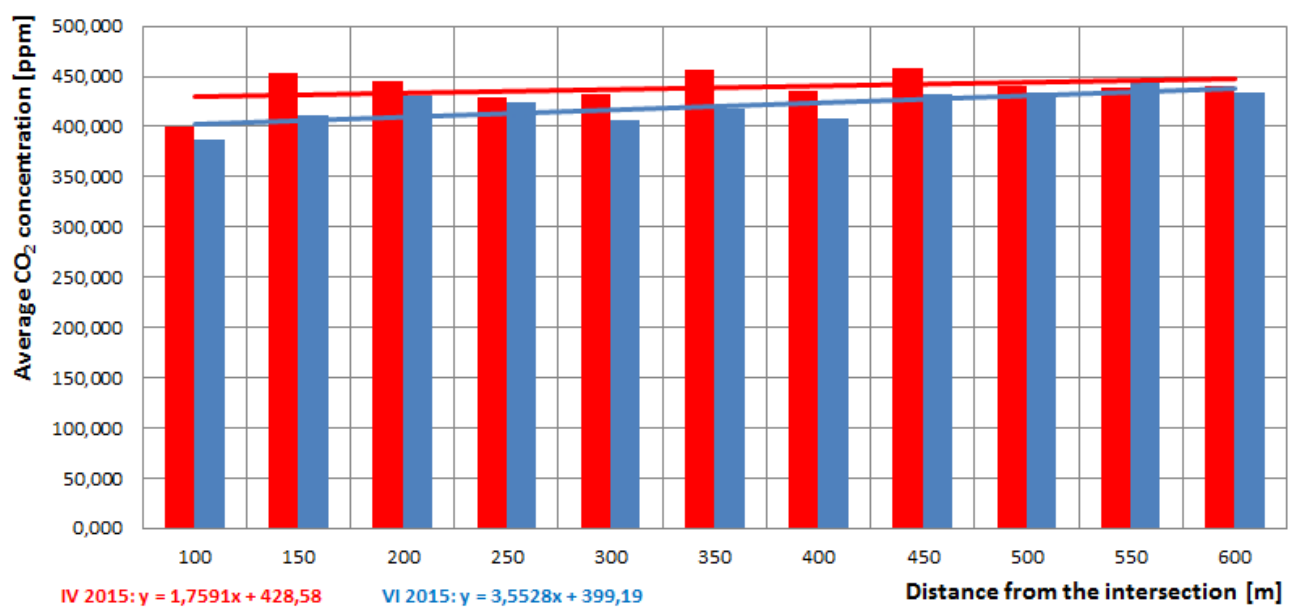

Fig. 4. Change in $\mathrm{CO}_{2}$ concentration depending on the distance from the intersection (April and June 2015).

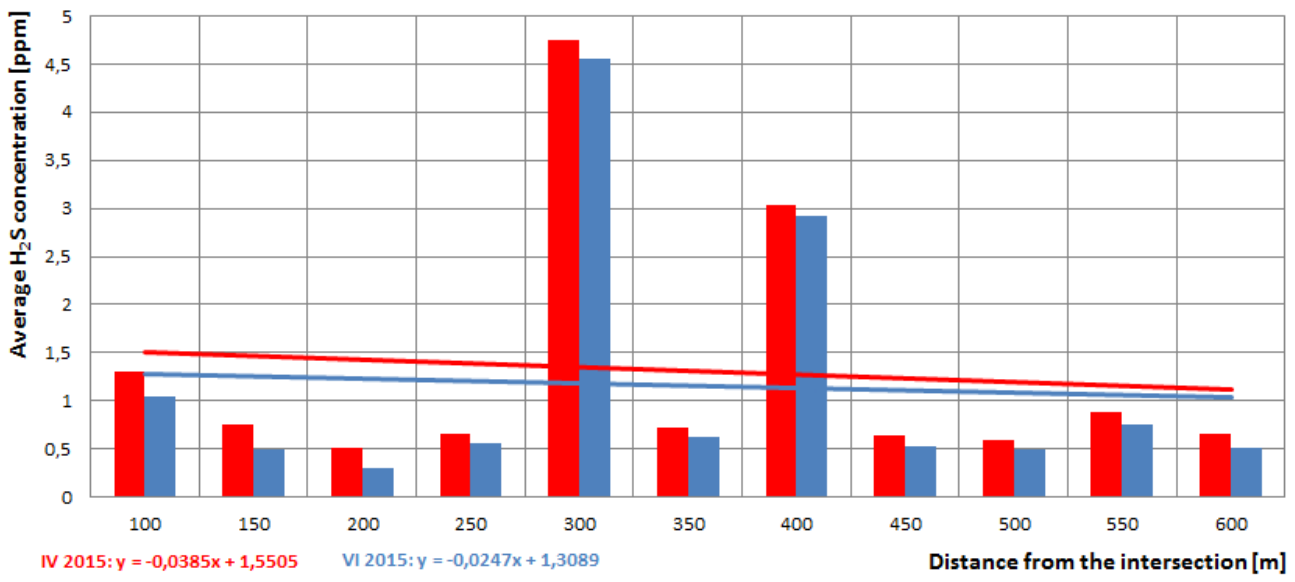

Fig. 5. Change in $\mathrm{H}_{2} \mathrm{~S}$ concentration depending on the distance from the intersection (April and June 2015). 
On the basis of the measured data (Fig. 4), the average concentration of $\mathrm{CO}_{2}$ was calculated for both series, which was 439.135 ppm and 420.503 ppm for April and June 2015 , respectively. Thus, the concentration was reduced by $4.43 \%$, but the level of pollutants in comparison to neighboring areas of public utility [32] was higher by about $13.51 \%$ on average.

In the analyzed period (Fig. 5), the average $\mathrm{H}_{2} \mathrm{~S}$ concentration was $1.319 \mathrm{ppm}$ for April 2015 and $1.161 \mathrm{ppm}$ for June 2015. So, there was a noticeable decrease in pollution amounting up to $13.65 \%$. The presence of this type of gas can be hazardous to the environment and is also associated with the remainder of technical infrastructure because hydrogen sulfide occurs in both channels, waste tanks and over cesspool surfaces.

At the same time, despite the significantly different 2 average levels of $\mathrm{H}_{2} \mathrm{~S}$ (300 and $400 \mathrm{~m}$ from the reference point), the linear trend of the slightly decline in pollutant concentrations is generally visible, which varies with the distance from the streets crossing. However, 2 very high concentrations of pollutant are most probably associated with point sources of pollutant emissions, i.e. residues of chemicals and technical infrastructure occurring in this area.

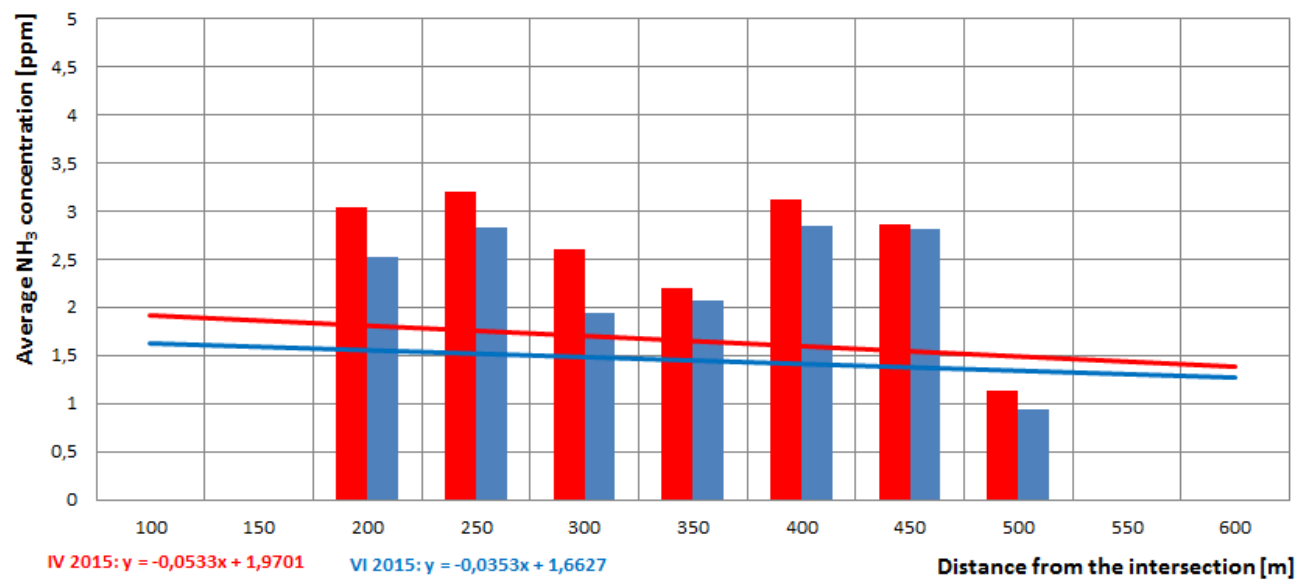

Fig. 6. Change in $\mathrm{NH}_{3}$ concentration depending on the distance from the intersection (April and June 2015).

The situation was similar for $\mathrm{NH}_{3}$ whose average level was 1.650 ppm for April 2015 and $1.451 \mathrm{ppm}$ for June 2015 , i.e. a $13.74 \%$ pollution reduction occurred.

In addition, literature data [36] have been analyzed, which shows that in 2015 all CHP plants in Lodz were responsible for $5.2 \%$ of the major pollutant emissions from point sources in the entire Lodz Province. All emissions from the CHP plants decreased by $17.2 \%$ year on year (probably due to the closure of EC-2 plant on March 31, 2015).

At the same time, based on [36] referring to air pollutants in 2015, the average annual concentration of $\mathrm{SO}_{2}$ ranged from 4 to $9 \mu \mathrm{g} / \mathrm{m}^{3}$, of $\mathrm{NO}_{2}$ exceeded $24 \mu \mathrm{g} / \mathrm{m}^{3}$ in the areas not directly affected by traffic emissions and was equal to $43.5 \mu \mathrm{g} / \mathrm{m}^{3}$ near the roadway. CO concentrations were $600 \mu \mathrm{g} / \mathrm{m}^{3}$ in city centers, while at main transport routes they ranged from 700 to $800 \mu \mathrm{g} / \mathrm{m}^{3}$. The last of the selected pollutants were PM10 and PM2.5, which in city centers ranged from $25.6 \mu \mathrm{g} / \mathrm{m}^{3}$ to $42.9 \mu \mathrm{g} / \mathrm{m}^{3}$ and from $21.1 \mu \mathrm{g} / \mathrm{m}^{3}$ to $22.1 \mu \mathrm{g} / \mathrm{m}^{3}$, respectively. 


\section{Summary}

The measurements and analysis of literature data [29] showed that the area of the former CHP plant had only slight environmental impact and did not exceed the permissible air quality standards.

The use of gas micro-chromatograph allowed accurate measurements of concentrations of carbon dioxide, hydrogen sulfide and ammonia as well as helped to investigate the influence of the communication path on the levels of particular pollutants.

The results are consistent with the trend observed in the city of Lodz where in recent years there has been a noticeable improvement in the quality of air, but this is not related to increasing exceedance of pollutant emissions associated with the use of low energy sources and the increasing number of mobile sources (rapidly increasing number of diesel vehicles).

It should be remembered that the role of the EC-2 CHP plant (as well as other CHP plants in Lodz) in shaping the air pollution immission fields in this city was small or even negligible owing to the size of the emitters and waste gas treatment installations. This is confirmed by the 'Air Protection Program in Łódź' in which the CHP plants are not indicated as a source of threats to the aerosanitary conditions in Lodz [36].

Such analyzes may help answer the question: whether and in what direction should reclamation and/or revitalization in a given post-industrial site be carried out and whether it is safe to use such degraded sites.

The author thanks Prof. Grzegorz Wielgosiński for help, valuable suggestions and opinions.

\section{References}

1. R. P. Schwarzenbach, T. Egli, T. B. Hofstetter, U. von Gunten, B. Wehrli, Annu. Rev. Env. Resour. 35, 109-136 (2010)

2. T. Asami, Contaminated Soil ' $88,261-263$ (1988)

3. D. Bucke, Symposia of the British Society for Parasitology 106, 1, S25-S37 (1993)

4. G. A. Folberth, T. M. Butler, W. J. Collins, S. T. Rumbold, Environ. Pollut. 203, 235$242(2015)$

5. R. Bossi, K. Vorkamp, H. Skov, Environ. Pollut. 217, 4-10 (2016)

6. A. de la Torre, P. Sanz, I. Navarro, M. Á. Martínez, Pollut. 217, 26-32 (2016)

7. D. T. Lobdell, V. Isakov, L. Baxter, J. S. Touma, M. B. Smuts, H. Özkaynak, Environ. Health Persp. 119, 487-493 (2011)

8. R. Cichowicz, G. Wielgosiński, W. Fetter, Environ. Monit. Assess. 189, 605 (2017)

9. G. Wielgosiński, R. Cichowicz, A. Targaszewska, J. Wiśniewski, Ecol. Chem. Eng. S. 24, 2, 263-275 (2017)

10. D. G. Atanassov, Int. J. Environ. Pollut. 14, 1-6, 217-224 (2000)

11. D. J. Nowak, S. Hirabayashi, A. Bodine, E. Greenfield, Environ. Pollut. 193, 119-129 (2014)

12. H. Flocas, A. Kelessis, C. Helmis, M. Petrakakis, M. Zoumakis, K. Pappas, Theor. Appl. Climatol. 95, 3-4, 265-277 (2009)

13. X. Tang, Urbanization, Energy, and Air Pollution in China: The Challenges Ahead: Proceedings of a Symposium, National Academies Press, 47-54 (2004)

14. B. Prieto, P. Sanmartín, Urban Pollution and Changes to Materials and Building Surfaces 5, 193-224 (2016) 
15. H. Martins, A. Miranda, C. Borrego, Air Pollution - A Comprehensive Perspective 2, 27-72 (2012)

16. G. Fernandez-Martinez, P. Lopez-Mahia, S. Muniategui-Lorenzo, D. Prada-Rodriguez, E. Fernandez-Fernandez, Atmos. Environ. 35, 5823-5831 (2001)

17. D. Li, Y. Guo, Y. Li, P. G. Ding, Q. Wang, Z. Cao, Open Journal of Air Pollution 1, 37-41 (2012)

18. Y. Qin, L. Y. Chan, Atmos. Environ. 27B, 275-282 (1993)

19. L. Y. Chan, Y. M. Liu, Atmos. Environ. 35, 2637-2646 (2001)

20. M. K. Ng, Soc. Indic. Res. 71, 1-3, 441-465 (2005)

21. E. Ozus, V. Dokmeci, International Real Estate Review 8, 1, 144-159 (2005)

22. M. Matysiak, Problemy Turystyki i Rekreacji (PTiR) 4, 46-70 (2013)

23. M. P. Johnson, Environ. Plann. A 33, 4, 717-735 (2001)

24. S. Angel, J. Parent, D. L. Civco, A. Blei, D. Potere, Prog. Plann. 75, 2, 53-107 (2011)

25. http://limitvalue.ifa.dguv.de/.

26. J. Stetkiewicz, Podstawy i Metody Oceny Środowiska Pracy 4, 70, 97-117 (2011)

27. RTECS, Registry of Toxic Effects of Chemical Substances (2007)

28. ACGIH, Guide to occupational exposure values, Cincinnati (2008)

29. Application for issuing an integrated permission (IPPC) for introduction of pollutants into the environment by the Zespół Elektrociepłowni in Łódź S.A. (ZEC) 5, Lodz University of Technology (2005)

30. G. Wielgosiński, Atmosphere Protection Analysis (Operat Ochrony Atmosfery) for ZEC in Łódź S.A. Department of EC-2, Lodz University of Technology (2004)

31. Google Earth 7.1.2.2041 (freeware)

32. Catalogue card of micro-chromatograph VEGA GC (DI-EN0022-1 VegaGC)

33. R. Cichowicz, G. Wielgosiński, Ecol. Chem. Eng. S. 22, 2, 189-200 (2015)

34. R. Cichowicz, G. Wielgosiński, Ecol. Chem. Eng. S. 22, 4, 513-525 (2015)

35. http://freemeteo.com/

36. Lodz: Regional Environment Protection Inspectorate, Report on the state of the environment in the Lodz region in 2015 (2016) 